\title{
Development of Mathematics Learning Books for Primary Teacher Education Students
}

\author{
E.Mailani $^{1 *}$, I.F.U.Manurung ${ }^{1}$, A.Simanihuruk ${ }^{1}$, Rahmulyani $^{1}$ \\ \{*elvimailani@gmail.com\} \\ Faculty of Education, Universitas Negeri Medan, Medan, Indonesia
}

\begin{abstract}
This study aims to compile a book for elementary mathematics learning media for students of the faculty of education, Medan State University. This elementary school mathematics learning book is compiled based on observations on lecturing time. It is seen that the learning resources used by the lecturers are dictates that have been prepared for a long time without being revised to upgrade the material contained in the dictates so that they are in accordance with the current curriculum. The specific objectives of this research are: developing a book of elementary mathematics learning media which will be used by students of the faculty of education in the lecturing process replacing the dictates they have been using. This research uses Developmental Research. The subject of this research is students of the faculty of education in Medan State University. In the early stages, observations were made during the lecture process and continued by conducting interviews with students. From the results of the observations and interviews, an initial draft of the elementary school mathematics learning book was compiled. Furthermore, the draft of the elementary mathematics learning media book was validated by a team that aims to assess the quality of the elementary mathematics learning books so that an effective learning media book will be compiled. The results targeted in this study are effective elementary mathematics learning books that will later be used by students of the Faculty of Education of Medan State University, replacing the long-used dictates.
\end{abstract}

Keywords: Books, learning media, mathematics, elementary school.

\section{Introduction}

Learning is a complex process that happens to everyone and lasts a lifetime, from the baby to the grave later. One sign that someone has learned something is a change in behavior in him. Changes in behavior are both knowledge (cognitive) and skills (psychomotor) as well as those relating to values and attitudes (affective). Learning activities can be done anywhere. Higher education is one of the institutions where humans learn. Learning activities in universities, especially in the faculty of education science (FIP) UNIMED is a process of interaction or reciprocity between lecturers and students which is the forerunner of education staff who will teach at the elementary school level after completing their education at the elementary school teacher education level (PGSD) at the faculty of education in Medan State University.

The lecture process that has been running in the faculty of education especially feels very lacking to be able to equip and facilitate students to have the skills needed when they later become educators after completing education at the faculty of education. Various skills that should be obtained that are needed in the learning process in the classroom, seem to have not 
been obtained clearly and in detail. This is because in the lecture process the teaching staff still uses learning resources (dictates) less in accordance with the development and demands of the needs in the current learning process in the classroom. The learning resources used by the teaching team tend to be long enough without any revisions at all. The use of such learning resources causes the ability of students in various matters to be still very low. One of them is the understanding of students in designing and using learning media needed for the teaching and learning process that is still very low,

The use of media in the learning process is expected to make the learning atmosphere more interactive, so that students will be able to explore all their abilities to find the concepts being studied. Besides that, with an interactive atmosphere where students are able to promote good communication with their own friends and with the teacher. Learning media developed by teachers are believed to be able to assist students in improving their learning achievement in school. Learning media should be designed and developed by the teacher before the learning process takes place. The ability to design and make learning media certainly does not come by itself, but must be trained and honed as often as possible. Provision of the ability to understand how to design and make learning media must be owned by a teacher so that later the teacher is able to design learning media that is appropriate to the needs of students in understanding a learning concept. All abilities and understanding of the media should be obtained by the teacher when the teacher studied at the university where he was studying.

The main problem of this study is that the learning resources used by teachers still focus on the use of dictates that have been made for a long time without any revisions being made. This causes the ability and understanding of students not to develop in accordance with the development of knowledge itself. Students do not have knowledge and understanding of new things. This is certainly very influential in the quality of prospective teachers who will be produced from this college. The faculty of education which should produce educators who are reliable and have good abilities when becoming teachers will not be realized.

Responding to the problems above this study aims to design a book of elementary school mathematics learning media which later can be used by students and the teaching team as a substitute for dictates that have always been used when face to face in lectures. This is considered very important because the ability of students to design learning media is needed when students become teachers. In addition, the materials that will be described in the elementary mathematics learning media book are materials that are in accordance with the media which is the learning material contained in the elementary mathematics education books. It is believed that with the use of this elementary mathematics learning media book, students will have the skills in designing elementary mathematics learning media which will be very useful for them later after becoming a teacher in elementary school.

Of the various problems described above, the focus of the problem that will be examined in this study is limited to the development of mathematics learning media books based on realistic mathematics using the 2013 scientific approach to curriculum that will be used for students of the State University of Medan PGSD replacing the dictate that has been used.

The formulation of the problem that can be developed from the limitation of the above problem is how the effectiveness and usefulness of the mathematics books based on realistic mathematics using the 2013 scientific approach to curriculum in providing insight to students of PGSD FIP Medan State University about mathematics learning media for elementary school students?

The purpose of this study is the development of elementary mathematics learning media books. The book of elementary mathematics learning media is expected to be used by students and lecturers in the lecture process at the faculty of education, Medan State University 
replacing the dictate that has been used. In addition, the book development of elementary school mathematics learning media is also expected to be able to open horizons for elementary school teachers in the city of Medan in designing and using learning media, especially mathematics media at the primary school level where they are assigned.

\subsection{Theoretical Review}

\subsubsection{Book}

Textbooks are books used by teachers as a reference source in the implementation of the learning process for the teaching participants [1]. There are three ways that teachers can use in compiling textbooks, namely repackaging information, writing themselves, and rearranging. Textbooks can also come from research results. Efforts that can be made to make researchbased textbooks are the way the author must first do research and report the results of his research.

Generally textbooks have several characteristics or characteristics such as: (1) using systematic structure and sequence of contents, (2) explaining instructional objectives to be achieved, (3) motivating students to learn, (4) anticipating student learning difficulties, (5) provide sufficient training for students, (6) provide a summary, (7) teaching materials are independent [2]. The existence of basic competencies (KD) and learning objectives that must be achieved by students, has forced teachers to develop teaching materials in accordance with it. Teaching materials will be more meaningful if the material contains contextual content and is in the student's daily environment [3].

\subsubsection{Media}

The word media comes from Latin and is a plural form of the word medium which literally means intermediary or introduction. Media is an intermediary or messenger from the sender to the recipient of the message. Media or teaching aids or audio-visual aids (A.V.A) are tools to help in learning. The teacher uses these tools when explaining the lessons to prevent verbalism (memorization or not understanding the clear meaning) According to Blake and Horalsen, media is a communication channel used to convey messages between sources (message providers) and recipients' message. Mc.Luhan, found that media is a channel, because it conveys the message (information) from the source of the information to the recipient of the information.

According to Hamidjo, media are all forms of intermediaries used by humans to convey or spread ideas so that ideas or opinions or ideas that are presented to arrive at the recipient in the broadest sense of the media are every person, material or event that gives learners the opportunity to gain knowledge, emptiness and attitude. In this sense teachers, textbooks, school environments are included.

In a narrow sense, the media is limited to printed materials, photographs, electronic goods, mechanical devices, compiled images and verbal information. From various views, it is concluded that the media is everything that can be used to channel messages from the sender to the recipient, so as to stimulate students' thoughts, feelings, attention and interests in a way that allows learning to occur.

\subsubsection{Mathematics Learning Media}

Mathematics lessons especially in basic education are now considered subjects that are very difficult to understand, mathematics learning requires very good reasoning, requires a high level of intelligence, not everyone can understand, so students are less interested in 
participating in this lesson. Students feel that the mathematics learning provided by the teacher has been less interesting, boring and there is no variation at all in the learning process. Teachers in mathematics studies should need to use the media in teaching mathematics so that the learning process becomes more interesting so that students are not bored, so that students can be more serious when learning and can easily accept and understand the mathematical concepts taught. As for other reasons mathematics learning requires media such as:

\subsubsection{Mathematical Objects are Abstract So That They Need Demonstration}

With mathematics learning tools, abstract mathematical material presented into a more concrete approach, there is visualization, and the benefits of learning the material in everyday life. Meanwhile, to teach mathematics correctly and effectively in absolute students must use teaching aids to facilitate students know the concept of mathematical concepts.

\subsubsection{Mathematical Material Is Not Easy to Understand}

Material from mathematics is abstract, this makes mathematics material not easily understood by most students. Therefore, with mathematics learning tools students are required to participate more actively, they not only see, hear and pay attention, but they also have to do / practice, so minds on and hands on learning can be achieved, the concept is built by the students themselves. For example: in the elimination method, if presented in props, each step that must be done is not memorized by students but understood, they build their own concepts and they know the reason for doing each step.

\subsubsection{Mathematical Hierarchy Is Strict and Rigid}

In mathematics, there are material preconditions needed to be able to step on the next material. The hierarchy of learning according to Gagne must be arranged from top to bottom or up down. It starts with placing the abilities, knowledge, or skills that are one of the goals in the learning process at the top of the learning hierarchy, followed by abilities, skills, or prerequisite knowledge that they must master first so they can learn the skills or knowledge above. Mathematical hierarchy is rigorous and rigid, meaning that in solving problems requires defined rules, principles and concepts as a prerequisite, which requires concrete concepts as the next prerequisite.

\subsubsection{Mathematical Applications Are Less Real}

It can be felt by students that the application of mathematics is less real, even students only assume that mathematics is a collection of numbers and symbols. Therefore, media is needed so that mathematics can be applied to everyday life. Thus, students can also easily learn concepts in mathematics.

\subsubsection{Learning Mathematics Needs to Be Focused}

Mathematics is not easy to understand, and its rigid hierarchy makes students difficult to learn mathematics. Therefore, students must focus when the teacher is explaining mathematics material, while most teachers use the lecture method in their learning. As a result, students become tired and bored in learning mathematics, therefore teachers are required to have creativity in learning mathematics. Teaching tools can help teachers to convey ideas or ideas in mathematics learning so that students are more active and not bored. 


\subsubsection{The Image of Mathematics Learning Is Not Good}

Students' current views on mathematics are not good, they think that mathematics learning is frightening, tense, bored and a lot of homework. This is because the teacher is unable to communicate rigid mathematics material so that it can be accepted and understood well by students. Mathematics learning in schools until now generally starts from the delivery of definitions or understanding of an object intuitively, followed by the operation of the object, and ends with giving examples then giving assignments or homework that is a lot as an exercise. In learning mathematics, many students assume that mathematics is difficult, full of formulas and numbers, so before the learning activities begin students have given up and feel they will not be able to master the subject matter to be delivered, this results in students being unable to actively participate in learning activities. Therefore, teaching aids can help teachers to change the paradigm that has been developing in society in general and students in particular.

\section{Methodology}

This chapter discusses systematically the method of developing a mathematics learning media book based on realistic mathematics using the 2013 scientific approach to the curriculum. The targeted research product is a book of mathematics learning media based on realistic mathematics using a scientific approach using a valid 2013 curriculum that will be used by faculty of education students of Medan State University in the field of elementary education.

\subsection{Type of Research}

This study uses development research methods to identify that developmental research is oriented towards product development where the development process is described as accurately as possible and the product is finally evaluated [5]. This research is also referred to as formative research where research activities are carried out in a cyclic process and are aimed at optimizing the quality of product implementation in certain situations [5]. In mathematics learning, this development research is applied in the repetitive activities of designing and testing the material products of mathematics learning [6]. The results of this study in the form of quality products theoretically, procedural methodology, and empirical.

This research activity was carried out in 2 (two) stages. Both stages are described as follows:

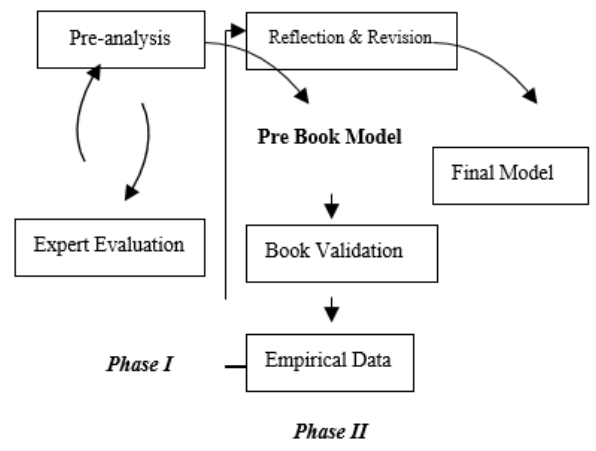

Fig. 1. The research activity 
Phase I of this study is called the front-end analysis phase which is aimed at analyzing and determining the book of mathematics-based mathematics learning media using the 2013 curriculum scientific approach. This activity is followed by developing materials that are in accordance with each basic competency in mathematical material. Through justification, analysis and evaluation of competent mathematics education experts and elementary school teachers, a mathematics learning media book based on realistic mathematics was developed using the 2013 curriculum scientific approach. This study involved experts in the development of mathematics education from the North Sumatra Province Education Agency and other mathematical learning experts.

The data for the development phase of the book of mathematics learning media based on realistic mathematics using the 2013 curriculum scientific approach was produced by validation conducted by teachers, principals and 3 lecturers from Medan state universities. Validation is carried out using a validation format that has been prepared by the expert team. The aspects that become references to book validation of mathematics learning media based on realistic mathematics using the 2013 curriculum scientific approach are:

(a) Suitability of media and materials with 2013 Curriculum

(b) suitability of language usage in accordance with the level and character of students.

(c) ease of media in providing students' understanding of the concept of the material being studied

(d) media image illustrations and catalogs for making media that are displayed are interesting, clear, and easy to understand

(e) ease of media to be replicated

The description of the research activities of mathematics learning media books based on realistic mathematics using the 2013 scientific approach to curriculum. The first phase of the research activity was carried out in Medan from April to August 2018. This study involved a validator team consisting of 3 mathematics education experts and 5 teachers.

The research activity began with the objective analysis activities carried out on January 22,2018 . The analysis of this objective was carried out to establish the basic direction and main objectives of development so that it could become the main benchmark in the development of realistic mathematics-based learning media books using the 2013 curriculum scientific approach. this is then compiled an appropriate alternative learning. In carrying out the analysis of objectives, viewed from the 2013 curriculum aspect. The subject developed in this mathematics learning media book is all the material contained in elementary mathematics lessons in the 2013 curriculum.

After the analysis of the objectives was completed, then on February 13, 2018 an analysis of the characteristics of students was carried out. Analysis of student characteristics is carried out through a study of student characteristics which include the level of cognitive development, ability, knowledge background, and socio-cultural background of students. From the results of this analysis will later be used as a reference frame in compiling a book of mathematics learning media based on realistic mathematics using the 2013 curriculum scientific approach.

The next activity in step 1 is the analysis of student needs. Analysis of student needs is carried out on February 26 to March 30 2018. Analysis of student needs is a review of the needs of faculty students at UNIMED education which includes the need to understand mathematical concepts, understanding in developing learning tools and how to design and use 
learning media they will use after finishing education at universities in Medan State University.

The next stage of the activity was to compile a validation instrument. This activity was carried out through the activity of designing a measurement tool that will be used to assess the quality of the teacher's book based on references and input from a team of experts and mathematicians. The validation instrument that will be used is expected to be a filter so that the mathematics learning media books based on realistic mathematics use the 2013 curriculum scientific approach that is developed to be of higher quality.

The most important activity in this study is the preparation of a draft book of mathematics learning media based on realistic mathematics using the 2013 curriculum scientific approach (7 May - 24 July 2018). This activity is carried out step by step so that the mathematics learning media books are designed in accordance with the references, concepts, indicators that have been developed and all the criteria that have been established in the design of this mathematics learning media book.

After the draft of the teacher's book was developed, the next activity was to validate the draft of the teacher's book, validation activities carried out by the validator team that had been appointed in this study. In validating the book of mathematics learning media based on realistic mathematics using the 2013 curriculum scientific approach, the validator team used a validation sheet that had been developed and designed in previous activities. This validation activity aims to produce a draft book of effective mathematics learning media and can help students of PGIP FIP Medan State University to improve their competence in mathematics subjects. The validation activity of the teacher book draft was held on 30 July to 11 September 2018.

\section{Result and Discussion}

\subsection{Result Validation of Expert Team}

Validation is carried out by teachers and expert teams from universities. The validator team validated using a validation sheet that was prepared in the research on the development of mathematics learning media books based on realistic mathematics using the 2013 scientific approach to curriculum. The validation results conducted by the validator team showed that the draft book of mathematics learning media based on realistic mathematics used the 2013 curriculum scientific approach already in good category. There are only a few in certain parts that must be revised and improved by the development team. Some input from the expert team as a validator team for realistic mathematics-based learning media using the 2013 curriculum scientific approach developed include: (a) The use of spelling that is still not consistent, (b) the clarity of language in the catalog each media still needs to be fixed, and (c) more media samples are added to facilitate student understanding.

In general, the validation results of the validator team for the development of mathematics learning media books based on realistic mathematics using the 2013 curriculum scientific approach can be seen below:

\subsubsection{Suitability of Media and Materials with the Curriculum Used}

The development of media and materials in the book of mathematics learning media is in accordance with the 2013 curriculum. In addition, the depth of material outlined is in accordance with the development of children in primary school. The material presented is very 
accurate and by showing the accuracy in applying the concept of geometry in flat building in a simple, clear, easy to understand, and appropriate usage according to the subject matter, the material is presented using standard Indonesian.

The media is presented up to date in accordance with the latest mathematical developments. Examples of media presented encourage students to try it in an effort to find the concept of the material being studied. Media that is displayed further can foster student creativity.

\subsubsection{Suitability of Language Use with The Level and Character of Students}

Sentences used to present the contents of a logical text and refer to the Indonesian sentence rules. Languages that are used are straightforward in accordance with students' thinking abilities. Examples can provide abstract concept clarity. The concept description is concrete, students can find it, and if the abstract can be imagined by students.

The message is presented in an interesting language, easy to understand, communicative, and encourages students to read thoroughly. The illustrations presented clarify the material described. Illustration comes from the surrounding environment in accordance with the field of science. The sentence used to convey the message refers to the Indonesian grammar rules Language used in explaining a concept in accordance with the development of students and in accordance with the level of emotional maturity of students.

\subsubsection{Ease of Media in Providing Understanding of The Concept of The Material Being Studied}

The media displayed is very helpful for students in understanding the various concepts being studied. This is because when students use the media, it is easy to answer various mathematical material concepts that are being studied with the help of the media contained in the learning media book.

\subsubsection{In the Pictures and Catalogs that Are Displayed Interesting, Clear and Easy to Understand}

The media images displayed in the book are very interesting for students. The media image is given a color printed clearly and attractively, giving rise to students' curiosity. In addition, all catalogs that are related to the media displayed are made in clear enough language so that students easily understand them. Steps that must be taken in making and using media are made in simple, coherent and clear language.

\subsubsection{Ease of Media for Replication}

The media displayed in the book, is a medium that is simple and easy to replicate and modify. Most media are made of simple materials that are easily found in the environment around students. Making media is very easy and harmless for students and teachers when using it.

\section{Conclusion}

This study aims to compile a book of realistic mathematics learning media using the 2013 curriculum scientific approach for students of PGIP FIP Medan State University as a 
substitute for the dictatorship that has been used in an effort to improve the ability to understand mathematics subject matter in elementary school.

The results of the validation of the draft book of mathematics learning media based on realistic mathematics using the 2013 curriculum scientific approach conducted by the validator team consisting of a team of teachers and lecturers from universities, showed that the mathematics learning media book based on realistic mathematics uses the 2013 curriculum scientific approach designed included in the good category.

\section{References}

[1] Ngadimun, Pedoman Umum Penulisan bahan Ajar -PDKLP. Malang: Pascasarjana Universitas Brawijaya, 2013.

[2] Suhardjono, "Menyusun Buku Ajar," Pelatih. Penulisan Buku Ajar Progr. Stud. Magister Pendidik. Guru Madrasah Ibtidaiyah PPS Univ. Islam Negeri Maulana Malik Ibrahim Malang, Sabtu 4 juni 2011, 2012.

[3] E. Peniati, "Pengembangan Modul Mata Kuliah Strategi Belajar Mengajar IPA Berbasis Hasil Penelitian Pembelajaran," J. Pendidik. IPA Indones., vol. 1, no. 1, 2012.

[4] W. A. Richey, R. C., \& Nelson, "Developmental Research," Handb. Res. Educ. Commun. Technol. 1213-1245, 1996.

[5] J. Van den Akker, "Principles and methods of development research," Des. approaches tools Educ. Train., no. Springer Netherlands, pp. 1-14, 1999.

[6] K. P. E. Gravemeijer, Developing realistic mathematics education: Ontwikkelen van Realistisch Reken/Wiskundeonderwijs. Nederlands: Freudenthal Institute, 1994. 